\title{
The Effect Of Patient Care Education On Burden Of Care And Quality Of Life Of Caregivers Of Stroke Patients [Corrigendum]
}

Hekmatpou D, Mohammad Baghban E, Mardanian Dehkordi L. J Multidiscip Healthc. 2019.20;12:211-217.

On page 211, the incorrect affiliation for author L Mardanian Dehkordi was inserted into the submitted manuscript and overlooked by the authors. The second affiliation should read as follows:

D Hekmatpou ${ }^{1}$, E Mohammad Baghban ${ }^{1}$, L Mardanian Dehkordi ${ }^{2}$
${ }^{1}$ Nursing Department, Arak University of Medical Sciences, Arak, Iran; ${ }^{2}$ Nursing and Midwifery Care Research Center, Department of Adult Health Nursing, School of Nursing and Midwifery, Isfahan University of Medical Sciences, Isfahan, Iran

\section{Publish your work in this journal}

The Journal of Multidisciplinary Healthcare is an international, peerreviewed open-access journal that aims to represent and publish research in healthcare areas delivered by practitioners of different disciplines. This includes studies and reviews conducted by multidisciplinary teams as well as research which evaluates the results or conduct of such teams or healthcare processes in general. The journal covers a very wide range of areas and welcomes submissions from practitioners at all levels, from all over the world. The manuscript management system is completely online and includes a very quick and fair peer-review system. Visit http://www.dovepress.com/testimonials. php to read real quotes from published authors. 